\author{
上原 伸夫 $^{1}$
}

\begin{abstract}
熱応答性高分子は代表的な機能性高分子であり, 高性能な分離分析システムの構築において盛んに研究さ れている材料の一つである，一方，金ナノ粒子は可視部に吸収を有することから，色彩変化を目視で観察で きるプローブとして医療診断の分野を中心に研究が精力的に行われている. 両者を複合化した熱応答性金ナ ノ複合体は，熱応答性高分子と金ナノ粒子それぞれの特徴を有するだけでなく，複合体としての新たな機能 を発現する. 本稿では, 熱応答性金ナノ複合体について分析化学的な応用を目指した研究に関し，チオール 化合物のセンシングを検討した著者らの研究を中心に紹介する.
\end{abstract}

\section{1 緒言}

熱応答性高分子は周囲の温度に応じて可逆的な相転移を 起こす機能性高分子の一種である ${ }^{1) \sim 3)}$. 代表的な熱応答性 高分子である $n$-イソプロピルアクリルアミドは, 相転移温 度以下に抏いてアクリルアミド基への水分子の水和により 親水性を示し, ランダムコイル状の構造をとる. その一方, 相転移温度以上の温度になると, アクリルアミド基の脱水 和によりグロビュール状（糸まり状に縮んだ状態）の凝集 体を形成する ${ }^{4) 5}$. この高分子の凝集体は均一な水溶液から 形成されるため，溶存成分を効果的に捕集することができ る. 熱応答性高分子を捕集材とする均一固相抽出法は, 齋 藤らによって精力的に開発されている ${ }^{6) \sim 9)}$. 相転移により 形成される凝集体は疎水的環境を有するため疎水性物質の 捕集に適している．またこの凝集体では，金属イオンなど 疎水性に乏しい分析対象物に対しても，疎水性錯体に誘導 するといったことで捕集が可能になる. さらに, 金属イオ ンの捕集能を熱応答性高分子に組み込むことで, 錯体に誘 導することなく金属イオンを捕集することも可能であ $ろ^{10) 11)}$.

金澤らは N-イソプロピルアクリルアミド共重合体を高 速液体クロマトグラフィー（HPLC）の固定相とすること で温度感応クロマトグラフィーを創出した ${ }^{1}$. 温度感応ク ロマトグラフィーではカラム温度を変えることで疎水性薬 物の保持特性を制御できる，ポリ（アクリルアミド）固定 相はオクタデシル固定相に比べ親水性であることから, 有 機溶媒を含む移動相を用いる必要がなく, 水系の溶離液で 十分な分離性能が達成されている，その他，熱応答性高分

E-mail : ueharan@cc.utsunomiya-u.ac.jp

${ }^{1}$ 宇都宮大学大学院工学研究科物質環境化学専攻 : $321-8585$ 栃 木県宇都宮市陽東 7-1-2
子はマイクロデバイスの流路の切り替え ${ }^{12)}$ のアクチュエー ターとしても研究されている ${ }^{13) 14)}$.な扔, 熱応答性高分子 全般として見ると，ドラッグデリバリーシステムへの応 用 ${ }^{15)}$ 18) が盛んに研究されている.

金ナノ粒子はその局所表面プラズモン共鳴に応じて可視 光領域から近赤外光領域の光を吸収する（厳密には消光と 呼ばれる). 分散状態にある粒径が十数 $\mathrm{nm}$ の金ナノ粒子の 場合, 波長約 $520 \mathrm{~nm}$ 付近に消光バンドが現れ，溶液は赤 色を呈する。この金ナノ粒子が㠜集すると，新たに長波長 側に消光バンドが出現し，溶液は青色へと変化する ${ }^{19) ~ 24)}$. この分散状態から凝集状態への金ナノ粒子のモルフォロ ジー変化に伴う色調変化はきわめて鋭敏であることから, 金ナノ粒子をべースとする色彩センサーが盛んに開発され てきた ${ }^{25) ~ 28)}$. 色彩センサー開発のストラテジーとして, 架 橋構造の形成に基づく方法が広く検討されている. 分析対 象物を介した架橋構造の形成により金ナノ粒子はすみやか に凝集する.この時生じる赤から青への色調変化が出力と して観察される. 架橋構造には, DNA の二重鎖 25) 29)30), キ レート形成 ${ }^{3133)}$, 抗原抗体反応 ${ }^{34) ~ 38)}$, 及び超分子構造 ${ }^{39}$ な どが報告されている。

熱応答性高分子と金ナノ粒子とを複合化した熱応答性金 ナノ複合体は, 両者の機能とは異なる新たな機能の発現が 期待される興味深い物質である ${ }^{26) 40) ~ 42)}$ ，熱応答性金ナ八 複合体の報告例としては，熱刺激による金ナノ粒子のモル フォロジー制御 ${ }^{43)}$ 45)，触媒活性の制御 ${ }^{46)}$ ，及び DNA への インターカレーション ${ }^{47)}$ に関する研究が報告されている. しかしながらこれまでのところ, 分析化学的なアプローチ は著者らのグループ以外には見当たらない. そこで本稿で はこれまでの著者らのグループが行ってきた熱応答性金ナ ノ複合体を用いるシステイン ${ }^{4849)}$ ，ホモシステイン ${ }^{50)}$ 及び グルタチオン ${ }^{51}$ に対するセンシングシステムへの適用例な 


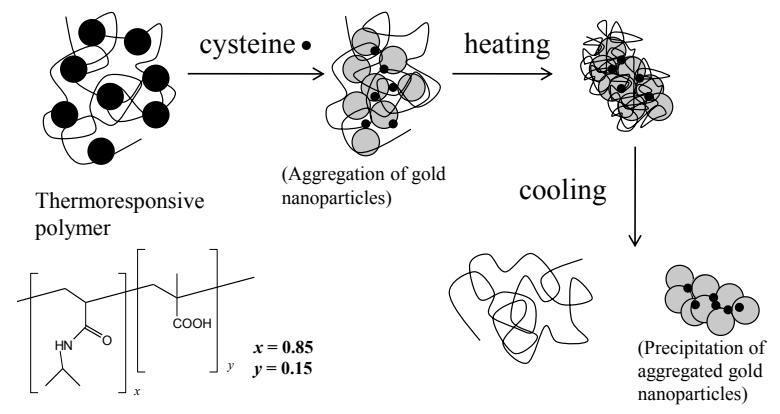

Fig. 1 Schematic of thermal-stimulated sedimentation of gold nanoparticles from thermoresponsive gold nanocomposites in the presence of cysteine

ど 52) 53) を中心にその分析化学的な可能性について概説す る.これらの化合物は, 金表面との親和性の強いチオール 基を有するぺプチドであり, 生体の代謝などにおいて重要 な役割を果たす ${ }^{54) ~ 58)}$. このため, 簡便で迅速な計測システ ムの開発が望まれている.

\section{2 熱刺激による熱応答性金ナノ粒子の沈降 ${ }^{48)}$}

分散状態にある金ナノ粒子はエネルギー的に不安定なた め, 表面に保護剤を修飾していないと外部からの刺激によ り容易に凝集する. 特に, システイン, ホモシステイン及 びその類縁体は分散状態にある金ナノ粒子を効果的に凝集 させる22(59) 63)．このときの赤から青への色調変化は鋭敏 であるものの, 凝集した金ナノ粒子は速やかに沈降してし まうため, 目視計測法へ展開するには定量性の面で課題が 残されていた.

金ナノ粒子の凝集を抑制するために，分散安定剤として 水溶性高分子が使われることがある. 熱応答性高分子は相 転移温度以下では水溶性高分子として振る舞うので, 相転 移温度以下で用いれば，金ナノ粒子の分散安定剂として利 用できる。また，熱応答性高分子による金ナノ粒子の分散 安定化は, 金ナノ粒子の機能化に対する重要なアプローチ の一つである. 実際, 熱応答性高分子としてメタクリル酸 を共重合したポリ（N-イソプロピルアクリルアミド-co-メ タクリレート) [p(NIP-MA)] を金ナノ粒子に複合化した熱 応答性金ナノ複合体を含む溶液にシステインを添加して も, 金ナノ複合体は沈降することはない.このとき, 複合 体内部に存在する金ナノ粒子は添加されたシステインによ り一部凝集する. その結果, 溶液は青色を帯びる. この溶 液を加熱すると, 相転移に伴い熱応答性高分子はグロ ビュール状の形態をとるようになる。これにより高分子は 水溶性を失い, 結果として溶液は濁る。このとき微視的に 見ると, 金ナノ粒子表面からの熱応答性高分子の遊離がシ ステインによって生じている. その後溶液を冷却すると, 熱応答性高分子の水溶性が回復し, 溶液は透明に戻る。し かしながら, 熱応答性高分子が金ナノ粒子から遊離してし
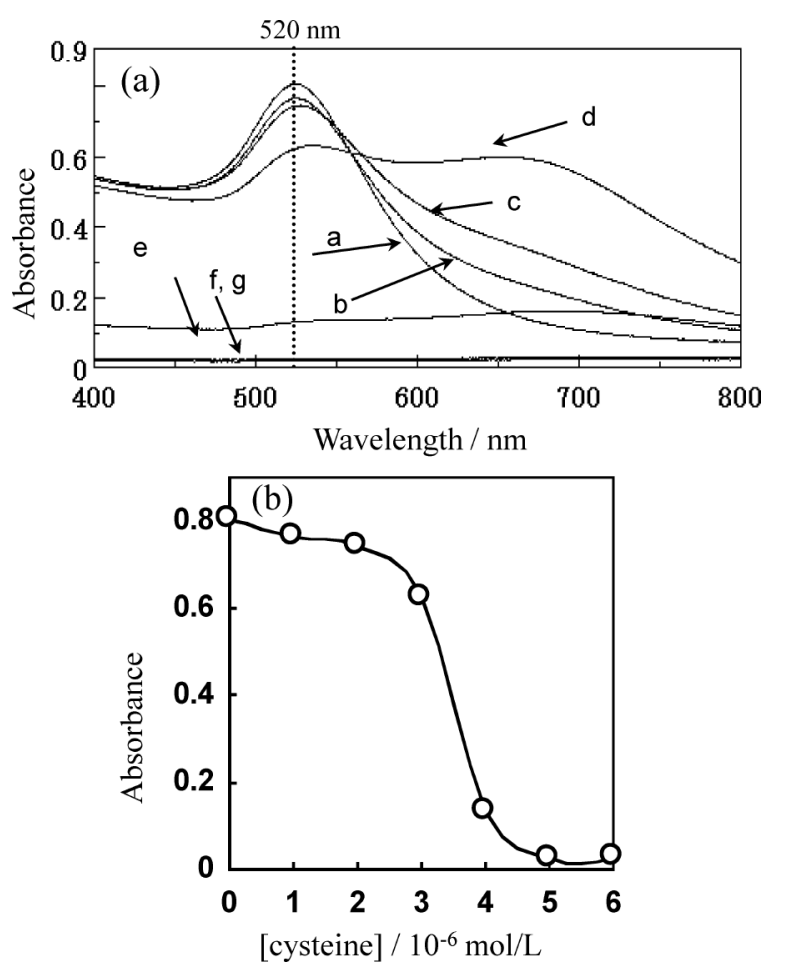

Fig. 2 (a) Visible spectra of thermoresponsive copolymer-conjugated AuNPs solution after heating followed by cooling. The solution contained gold nanoparticles of $0.054 \mathrm{~g} \mathrm{dm}^{-3}$, thermoresponsive copolymer [poly $(N$-isopropylacrylamide) (85 mol\%)$c o-N$-methacrylic acid $\left.\left(15 \mathrm{~mol}_{\mathrm{O}}\right)\right] 10 \mathrm{~g} \mathrm{dm}^{-3}$, and cysteine of a), $0 \mathrm{~mol} \mathrm{dm}^{-3}$; b), $1.0 \times 10^{-6} \mathrm{~mol} \mathrm{dm}^{-3}$; c), $2.0 \times 10^{-6} \mathrm{~mol} \mathrm{dm}^{-3}$; d), $3.0 \times 10^{-6} \mathrm{~mol} \mathrm{dm}^{-3}$; e), $4.0 \times 10^{-6} \mathrm{~mol} \mathrm{dm}^{-3}$; f), $5.0 \times 10^{-6} \mathrm{~mol} \mathrm{dm}^{-3}$; g), $6.0 \times 10^{-6} \mathrm{~mol} \mathrm{dm}{ }^{-3}$. (b) Plots of absorbance measured at $520 \mathrm{~nm}$ vs. concentration of cysteine. Reproduced with permission from Ref. 48 ; (C) The Japan Society for Analytical Chemistry.

まったことにより，凝集していた金ナノ粒子は沈降する. この変化を Fig. 1 に模式的に示す. また実際の溶液のスぺ クトル変化と $520 \mathrm{~nm}$ における吸光度の変化を Fig. 2 に示 す．添加するシステイン濃度の増加とともに，分散状態に

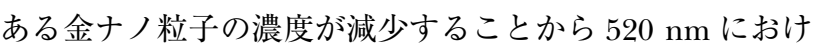
る吸光度は低下する。しかしながら，この溶液においてス ペクトルの経時変化はほとんどみられない.これは, 熱応 答性高分子の金ナノ粒子に対する分散安定性によるものと 考えられる．熱応答性高分子による分散安定性はこの系に 優れた再現性を与える. Fig. 2 に示した $520 \mathrm{~nm}$ の吸光度と システイン添加量との関係は直線性を持たないものの, シ ステインの吸光光度定量に用いることができる.

3 凝集状態にある熱応答性金ナノ粒子の熱刺激に よる再分散 ${ }^{49)}$ ５2)

前項でも述べたように，分散状態にある金ナノ粒子は高 い表面エネルギーを有することから凝集しやすく，一旦凝 
集してしまうと再び分散状態に戻すことは難しい。凝集し てしまった金ナノ粒子を分散状態に戻すために，金ナノ粒 子表面の電荷反発の発現が検討されている ${ }^{64)}$. 溶液の $\mathrm{pH}$ をアルカリ性にすることで，金ナノ粒子表面に付着してい る修飾剤の官能基が解離し, 表面は負に带電する. 結果と して，凝集していた金ナノ粒子は電荷反発により再度分散 するようになる。しかしながら，これまでのところ液性を 変化させることなく金ナノ粒子の再分散を行った報告はな されていない.

熱応答性高分子にポリアミノ基の一種であるトリエチレ ンテトラミン基を共重合させたポリ（ $N$-イソプロピルアク リルアミド-co-アクリロイルトリエチレンテトラミン) [p(NIP-TETA)］を分散している金ナノ粒子に複合化させ

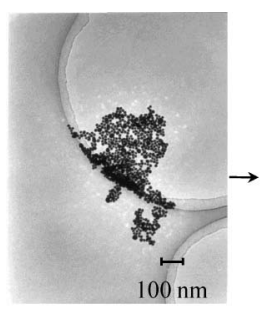

(a) Without heating

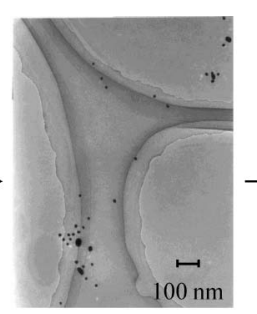

(b) First heating

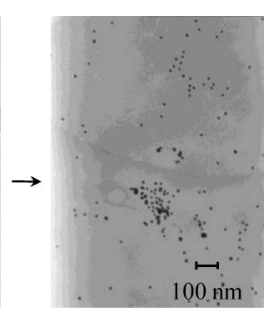

(c) 2nd heating
Fig. 3 TEM images of 13-nm gold nanoparticles conjugated with thermoresponsive polymer having polyamino groups

(a) Without thermal stimuli (heating followed by cooling), (b) one cycle of thermal stimuli, and (c) two cycle of thermal stimuli. Reproduced with permission from Ref. 49 ; (C) American Chemical Society.
ると，トリエチレンテトラミン基により金ナノ粒子は凝集 し，その溶液は青色を呈する。この場合も熱応答性高分子 が分散剂として作用しているため，金ナノ粒子は凝集して いるものの沈降することない．この溶液を加熱すると，熱 応答性高分子は相転移を起こし溶液は濁る。このとき金ナ ノ複合体の中で凝集していた金ナノ粒子は，相転移に伴う 高分子鎖の収縮により再び分散状態に戻る。このとき, 濁った溶液の色調は青色から赤色へと変化するようにな る.この溶液を泠却すると, 再び赤色の透明な溶液となる. Fig. 3 に示した透過型電子顕微鏡（TEM）像から, 金ナノ 粒子は分散状態に戻っていることが確認された。

熱刺激により熱応答性金ナノ複合体中の金ナノ粒子が再 分散する様子を Fig. 4 に模式的に示す. p(NIP-TETA) はト リエチレンテトラミン基を介して金表面と強く相互作用 し，金ナノ粒子の凝集を引き起こす，金ナノ粒子表面に結 合した $\mathrm{p}$ (NIP-TETA) は，溶液の加熱により脱水和を起こ し，高分子鎖を収縮させる，このときトリエチレンテトラ ミン基を介してポリマーが金ナノ粒子に結合しているため に，金ナノ粒子間に収縮した熱応答性高分子が入り込むよ うになり，ナノ粒子間の距離が広がる。次いで溶液を冷却 すると，収縮していた分子鎖への水和により $\mathrm{p}$ (NIP-TETA) は膨潤し，金ナノ粒子の再分散が進む。

ポリアミノ基は熱応答性高分子が金ナノ粒子表面に吸着 するためのアンカーの役割を担っており，再分散において 重要な役割を果たす。ポリアミノ基のエチレンアミンュ ニットが長くなるほど，金表面へ強く吸着するようになる ので, 再分散は効果的に生じる. 検討した中では, 三つの エチレンアミンユニットから構成されるトリエチレンテト

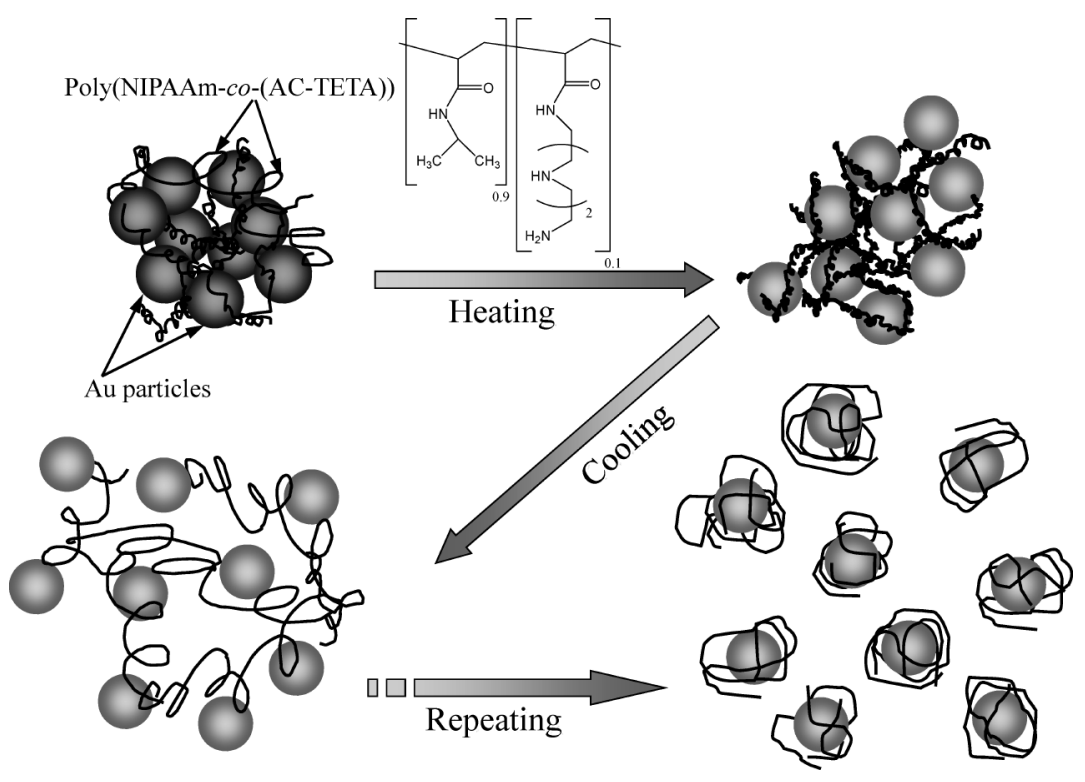

Fig. 4 Schematic of thermal-stimulated disassembly of assembled gold nanocomposites

Reproduced with permission from Ref. 49 ; (c) American Chemical Society. 
ラミンを組み込んだ $\mathrm{p}$ (NIP-TETA) が最も良い結果を与え た.エチレンアミンユニットが四以上のポリアミノ基では より効果的な再分散を期待できるものの，高分子鎖への効 率的な官能基の導入といった合成上の課題があるため, こ れについては未検討である.

溶液の加熱温度は再分散において非常に重要な因子であ る. Fig. 5 に各加熱温度における溶液のスペクトルを示す. 興味深いことに，金ナノ粒子の再分散は熱応答性高分子と して用いた $\mathrm{p}$ (NIP-TETA) の相転移温度（約 $34{ }^{\circ} \mathrm{C}$ ）付近で は生じず，それよりも高い温度において温度の上昇ととも

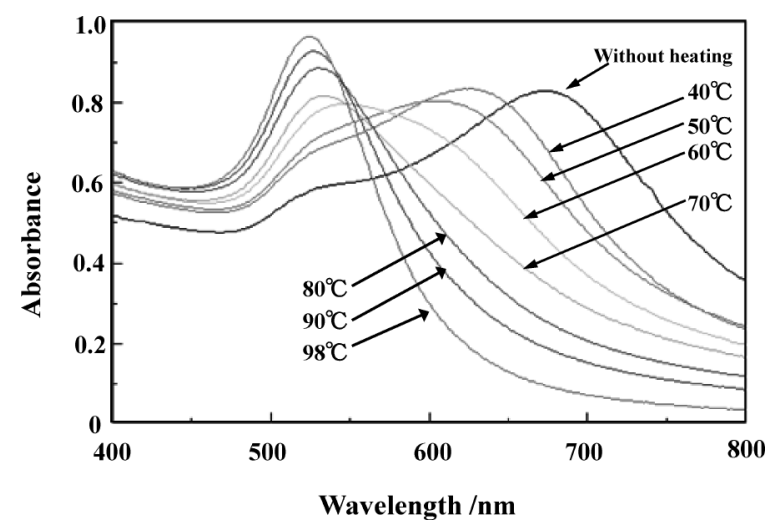

Fig. 5 Effect of heating temperature on the visible spectra of gold nanocomposite solutions

The solutions containing gold nanoparticles of 0.054 $\mathrm{g} / \mathrm{L}$ and thermoresponsive copolymer, p(NIP-TETA), of $2 \mathrm{~g} / \mathrm{L}$ was heated in the range between 40 and $98{ }^{\circ} \mathrm{C}$ for $30 \mathrm{~min}$ followed by cooled at $4{ }^{\circ} \mathrm{C}$. Reproduced with permission from Ref. 49 ; (C) American Chemical Society.
に進行する．このことは，再分散が熱応答性高分子のマク 口な物性である相転移とは直接関連していないことを示し ている，抽らく，ポリアミノ基を介して金ナノ粒子表面 に結合した熱応答性高分子では，コンフォメーションの変 化に際して自由度が低下しているものと推測される。これ により，N-イソプロピルアクリルアミド基からの脱水和が 生じても高分子鎖は容易には収縮しないものと考えられ る.このため, 金ナノ粒子に結合したポリマー鎖の収縮に は相転移温度以上の加熱を要する。

$3 \cdot 1$ 熱刺激による熱応答性金ナノ粒子の再分散に及ぼ すチオール化合物の添加効果

チオール化合物はチオール基を介する共有結合により金 表面と強く吸着する。これにより, 熱応答性金ナノ複合体 の再分散に対して著しい影響を及ぼす。再分散に及ぼす影 響の程度に基づいてチオール化合物を分類した結果を Table 1 に示す. 検討した大部分のチオール化合物は再分 散を抑制する。しかしながら，興味深いことに，ジペプチ ドのグルタミルシステインとシステイニルグリシン及びト リペプチドであるグルタチオンは再分散を促進することが 分かった. 一方, チオール基を持たない化合物は含硫化合 物（モノスルフィド及びジスルフィド）であっても再分散 には影響しない.

Table 1 に示されるように，チオール化合物が及ぼす再 分散の抑制, 促進効果と金ナノ粒子の分散安定化効果との 間には強い相関関係がある。ここではチオール基の分散安 定化効果を，溶液の $\mathrm{pH}$ を酸性から塩基性へまたその逆へ と繰り返し変化させた時の色調変化の可逆性として評価し

Table 1 Effects of sulfhydryl compounds on stabilization of bare gold nanoparticles and disassembly of gold nanocomposites with thermoresponsive polymers

\begin{tabular}{|c|c|c|}
\hline Compound & Stabilizing ability & $\begin{array}{c}\text { Facilitation or inhibition } \\
\text { of disassembly }\end{array}$ \\
\hline Glutathione & excellent $^{\text {a) }}$ & facilitation $^{\mathrm{e})}$ \\
\hline Glutamylcysteine & excellent & facilitation \\
\hline Cysteinylglycine & excellent & facilitation \\
\hline Phytochelatin & excellent & no response \\
\hline$N$-Acetylcysteine & $\operatorname{good}^{b)}$ & inhibition \\
\hline Penicillamine & good & inhibition \\
\hline 3-Mercaptopropionic acid & poor $^{c)}$ & inhibition \\
\hline Cysteine & poor & inhibition \\
\hline Homocysteine & quite poor ${ }^{\mathrm{d}}$ & inhibition \\
\hline 2-Mercaptoethanol & quite poor & inhibition \\
\hline 1,2-Ethanedithiol & quite poor & inhibition \\
\hline
\end{tabular}

a) "Excellent" means a reversible response to $\mathrm{pH}$ swing. b) "Good" means a partially reversible response. c) "Poor" means irreversible response. d) "Quite poor" means an immediate aggregation of gold nanoparticles irreversibly. e) Glutathione facilitates spontaneous disassembly of gold nanocomposites without thermal stimuli.

Solutions containing $0.054 \mathrm{~g} \mathrm{dm}^{-3}$ gold and $2 \mathrm{~g} \mathrm{dm}^{-3}$ poly $\left(\mathrm{NIP}_{0.9}-\mathrm{TETA}_{0.1}\right)$ were heated between $40{ }^{\circ} \mathrm{C}$ and $98{ }^{\circ} \mathrm{C}$ for $30 \mathrm{~min}$ followed by cooling at $4{ }^{\circ} \mathrm{C}$. 

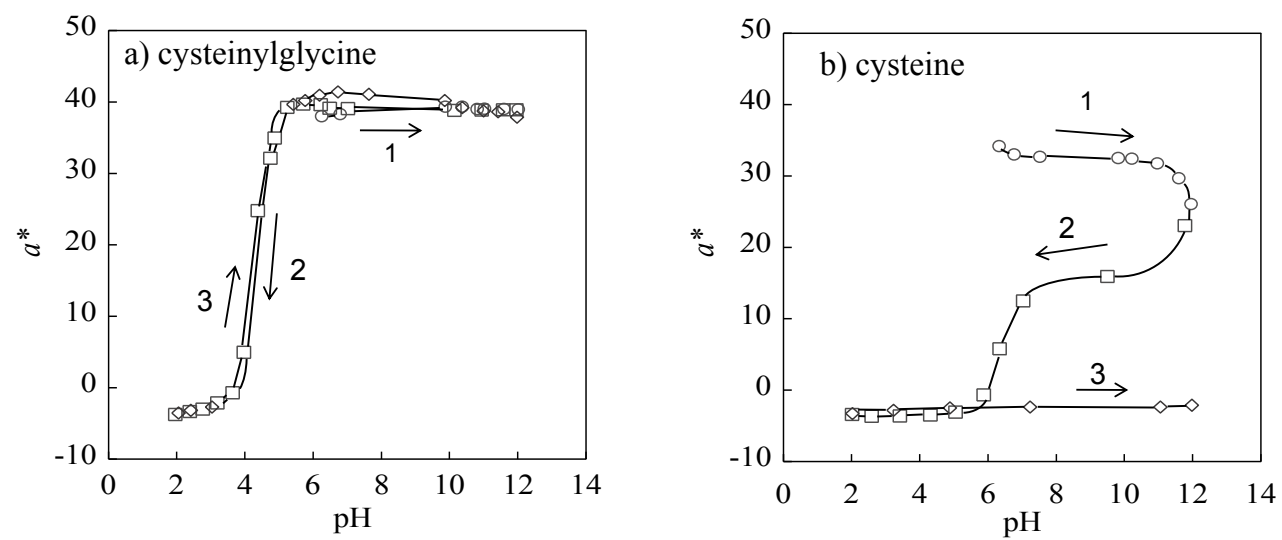

Fig. $6 \mathrm{pH}$ dependence of $a^{*}$ value of a solution containing gold nanoparticles of 0.054 $\mathrm{g} / \mathrm{L}$ and a) cysteinylglycine of $1 \times 10^{-5} \mathrm{~mol} / \mathrm{L}$, b) cysteine of $1 \times 10^{-5} \mathrm{~mol} / \mathrm{L}$

The numbers with arrows indicate sequences of $\mathrm{pH}$ swing. Reproduced with permission from Ref. 52 ; ( ) The Japan Society for Analytical Chemistry.

た. 色調変化の出力には $L^{*} a^{*} b^{*}$ 表色系を用いた. 高い分散 安定性を与えるチオール化合物を吸着した金ナノ粒子で は, $\mathrm{pH}$ 変化に応じて可逆的な色調変化を示す．この典型 例として，システイニルグリシンを被覆した金ナノ粒子の $\mathrm{pH}$ 応答を Fig. 6 a に示す. 溶液は酸性条件で青色（凝集状 態), 塩基性条件で赤色 (分散状態) となる可逆的な応答を 示す．類似した可逆的な応答がグルタチオンを被覆した金 ナノ粒子でも報告されている ${ }^{61)}$ 。これに対して，分散安定 性の低いチオール化合物を吸着した金ナノ粒子の場合に は，酸性条件で㠜集状態になった金ナノ粒子は塩基性にし ても分散状態には戻らない.この典型例としてシステイン を被覆した金ナノ粒子において得られた結果を Fig. 6 bに 示す.

Table 1 はまた, チオール化合物が金ナノ粒子に与える 分散安定性とチオール化合物の分子構造とに関連性がある ことを示している，チオール基を持つペプチドを例にとる と, モノペプチド（システイン及びホモシステイン）は分 散安定性を低下させ (すなわち, 再分散を抑制し), ジペプ チド（システイニルグリシン及びグルタミルシステイン） 及びトリペプチド（グルタチオン）は分散安定性を向上さ せる（再分散を抑制させる）。 Table 1 に示したチオール化 合物について, 親水性官能基の種類, 数と分散安定性との 関係を見ると, カルボキシル基は金ナノ粒子の分散安定性 を向上させる，その一方で，アミノ基やヒドロキシル基は 分散安定性を低下させる傾向がある。 また，ペプチドの場 合, 分子が袈高くなるほどその分散安定性が向上してい る.このことから，吸着した分子の専有面積が大きくなる ことで金ナノ粒子の分散安定性を向上させていることが示 唆される. これに対して, ファイトケラチン（チオール基 を有するオリゴペプチド）は，分子サイズが大きいため， 金ナノ粒子を被覆している熱応答性高分子層を通過できず
金表面には到達しない。このためファイトケラチンは金ナ ノ粒子を安定化するものの，再分散には影響を及ほさな い.

上述の結果は添加されたチオール化合物が熱応答性金ナ ノ複合体中の金ナノ粒子の表面に吸着し，その分散安定性 に寄与していることを示唆している。これを確かめるため に質量分析装置で金ナノ複合体を測定した．チオール化合 物が共存しない場合，エチレンジアミン残基の付着した金 クラスターの質量スペクトルが観察された（Fig. 7)。その 一方で，チオール化合物を添加した場合には，エチレンジ アミン残基の付着した金クラスターの質量スペクトルが消 失し, 代わってチオール化合物に由来する硫黄原子が吸着 した金クラスターの質量スペクトルが観察されるように なった．この結果から，熱応答性ナノ複合体では，熱応答 性高分子のポリアミノ基が金ナノ粒子の表面に結合して㧈 り，添加されたチオール化合物が金ナノ粒子表面に結合す る際に，ポリアミノ基の脱離を引き起こしていることがう かがえる. ポリアミノ基の脱離によりポリマーが金ナノ粒 子から遊離するため, 最終的な金ナノ粒子の安定性は吸着 しているチオール化合物自身の持つ金ナノ粒子安定性に依 存するものと考えられる.

\section{$3 \cdot 2$ 再分散の抑制に基づくチオールセンシング 49)50)}

前項で示したチオール化合物による再分散への促進, 阻 害効果に基づいて，チオール化合物の目視計測システムを 構築した．加熱冷却後の熱応答性金ナノ複合体は金ナノ粒 子の凝集・分散にかかわらず水中で安定に存在できるの で, 再現性の高い結果を与える. このことは, 分散状態か ら凝集状態への色調変化を観察する従来型の色彩セン サー ${ }^{24) \sim 38)}$ に比べると定量性の面に扔いて有利である. 再 分散を抑制するシステインの場合, $10^{-6} \mathrm{~mol} \mathrm{dm}^{-3}$ レベル 

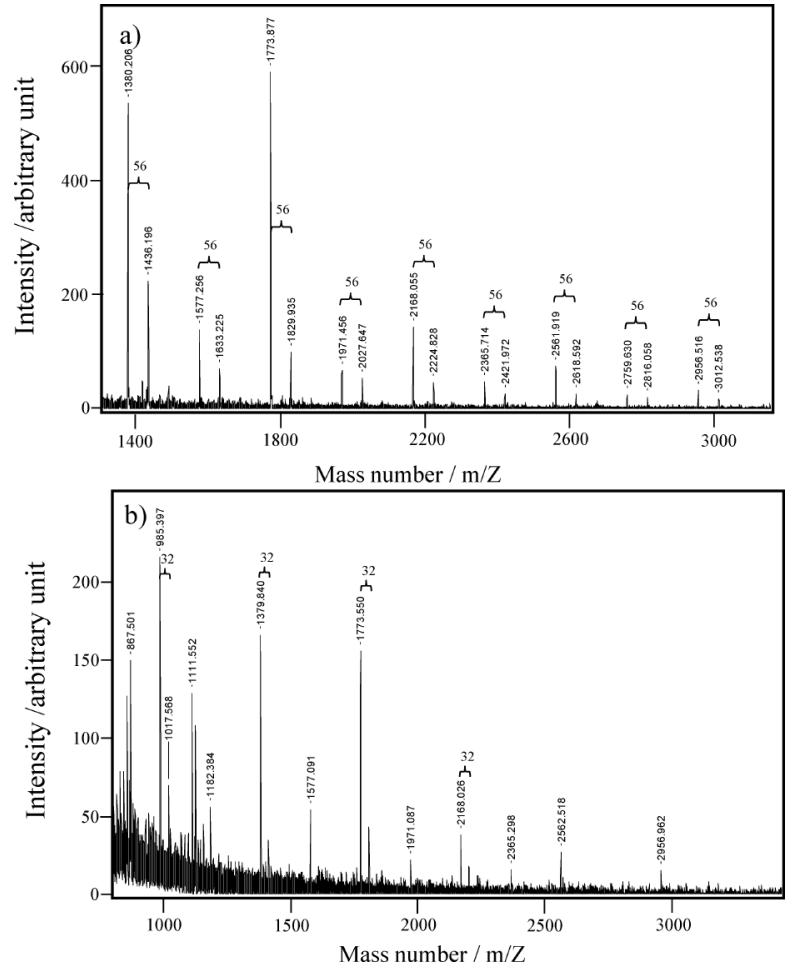

Fig. 7 Mass spectra of (a) gold nanocomposites conjugated with poly $\left(\mathrm{NIP}_{0.9}-\mathrm{TETA}_{0.1}\right)$ and (b) gold nanocomposites conjugated with poly $\left(\mathrm{NIP}_{0.9}-\mathrm{TETA}_{0.1}\right)$ and cysteine. Differences of mass number 56 in (a) and 32 in (b) are ascribed to a residue of ethyleneamine $\left(\mathrm{NCH}_{2} \mathrm{CH}_{2} \mathrm{~N}\right)$ and a sulfur atom, respectively

Reproduced with permission from Ref. 49 ; (C) American Chemical Society.

において, システインの増加とともに, 再分散が阻害され るため, 溶液は赤色に戻りにくくなり,$a^{*}$ 值は低值とな る. システインと $a^{*}$ 值との関係を検量線として用いること でサプリメント中のシステインを定量することができる.

被覆する熱応答性高分子の種類を変えることで, 熱応答 性金ナノ複合体の持つチオール化合物への応答性を制御で きる．熱応答性高分子であるポリ（N-イソプロピルアクリ ルアミド-co-メタクリル酸-2- ジメチルアミノエチル) [p(NIP-DEAEMA)］を被覆した熱応答性金ナノ複合体は, チオール化合物による抑制効果に対する応答性が鈍いた め, $10^{-6}$ から $10^{-5} \mathrm{~mol} \mathrm{dm}{ }^{-3}$ レベルのシステインには応答 しない.これに対してホモシステインは, 金ナノ粒子に対 して非常に大きな凝集効果を持つことから ${ }^{58) 60)}, 10^{-6}$ から $10^{-5} \mathrm{~mol} \mathrm{dm}{ }^{-3}$ の濃度範囲でこの熱応答性金ナノ複合体の 再分散を阻害する．結果としてこの熱応答性金ナノ複合体 ではホモシステインに対する選択性が向上する ${ }^{50)}$. ホモシ ステインとシステインとはメチレン鎖一つだけの違いしか なく, クロマトグラフィーでも電気化学的手法でも両者の 識別は非常に難しい. p(NIP-DEAEMA) を被覆した熱応答
性金ナノ複合体はシステインの共存に影響されないことか ら，この方法はホモシステインを計測するプローブとして 有望である.

\section{$3 \cdot 3$ 自発的な再分散に基づくグルタチオンのセンシング ${ }^{51)}$}

Table 1 に示すようにチオール基を有するトリペプチド であるグルタチオンは熱刺激による金ナノ複合体の再分散 を促進する．金ナノ粒子に被覆する熱応答性高分子を $\mathrm{p}$ (NIP-TETA) からポリ（N-イソプロピルアクリルアミ ド-co-アクリロイルジエチレントリアミン) [p(NIPDETA)］に変更し調製した熱応答性ナノ複合体を用いる と, グルタチオンを添加しただけで，加熱といった熱刺激 を加えることなく再分散が進行することを見いだした．ジ エチレントリアミン基はトリエチレンテトラミン基よりエ チレンアミンユニットが一つ少ないので, 金ナノ粒子への 結合力が弱くなる.このため, グルタチオンの吸着により, 自発的に金ナノ粒子から遊離するものと推測される。この ときの変化を模式的に Fig. 8 に示す. 熱応答性金ナノ複合 体の中に存在する金ナノ粒子は凝集状態にあるものの, 熱 応答性高分子が被覆されていることにより，互いに融合す ることはない.グルタチオンがチオール基を介して金ナノ 粒子と結合する際に, 熱応答性高分子のジエチレントリア ミン基は金表面から遊離する。トリペプチドであるグル夕 チオンは嵩高いため, グルタチオンの吸着は金ナノ粒子の 分散安定性を向上させる. この結果, 自発的に再分散が進 行する. 添加するグルタチオンの濃度が増加するにつれ て, また, 経過時間が長くなるにつれて再分散が進み溶液 の赤みが増す．このときの $a^{*}$ 值の変化を Fig. 9 に示す.

\section{$3 \cdot 3 \cdot 1$ 再分散の阻害・促進の拮抗に基づく酵素活性の} 計測 ${ }^{52)}$ 53) チオール化合物による再分散への影響の違い を上手く組み合わせることで, チオール化合物の分解反応 に関与する触媒の活性度を計測することができる．例え ば，ジペプチドであるシステイニルグリシンが再分散を促 進し, システインが再分散を抑制することを利用して, シ ステイニルグリシン分解酵素（CD-13）の活性を色彩計測 することができる ${ }^{52)}$. CD-13 は腫瘍マーカーとしても注目 されている酵素である ${ }^{65) ~ 67)}$. 一方, グルタチオンとシステ イニルグリシンの再分散に対する促進効果の違いに基づい てグルタチオン分解酵素（ $\gamma-\mathrm{GTP} ）$ を計測することもでき $ろ^{53)}$. $\gamma$-GTP 活性は肝機能の指標として臨床診断に用いら れている。

Fig. 10 に CD-13 活性及び $\gamma$-GTP 活性を目視計測する原 理について模式的に示す. CD-13 活性を測定する場合, 酵 素活性が高い程あるいは酵素と基質との反応時間が長い 程，システイニルグリシンが消費され，それに応じてシス テインが生成するので，再分散が抑制される，このときグ リシンは再分散の促進・抑制には関与しない.このため, 


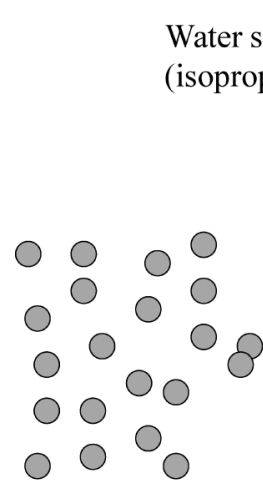

Discrete AuNPs
Water soluble copolymer (isopropylacrylamide copolymer)

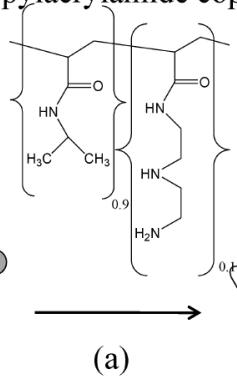

(a)

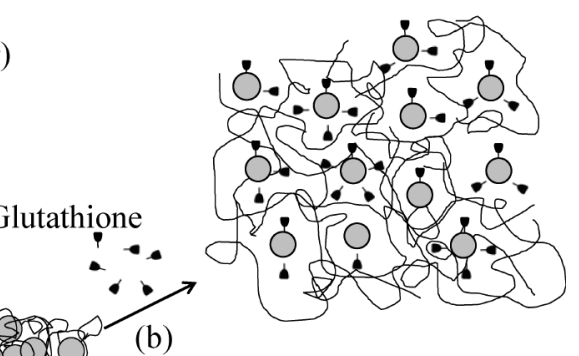

Au nanocomposites

Heating followed

by cooling (c)

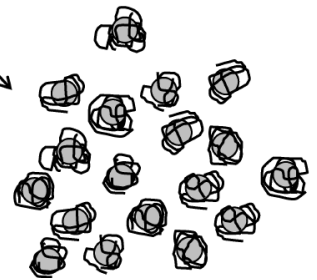

Fig. 8 Schematic of the spontaneous disassembly of assembled gold nanocomposites driven by glutathione

Reproduced with permission from Ref. 51 ; (c) American Chemical Society.

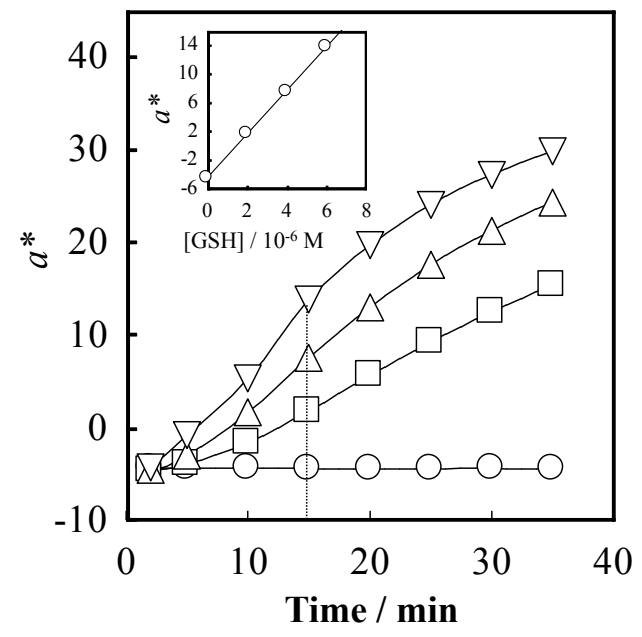

Fig. 9 Relationship between the $a^{*}$ value of a thermoresponsive gold nanocomposite solution and the concentration of glutathione under prescribed standing times

The solution, which contained $0.054 \mathrm{~g} / \mathrm{L}$ gold nanoparticles, $2 \mathrm{~g} / \mathrm{L} \mathrm{p}$ (NIP-DETA) and glutathione with prescribed concentrations, was left standing for prescribed times at $25{ }^{\circ} \mathrm{C}$. Concentrations of glutathione were as follows : $\bigcirc, 0 \mathrm{~mol} / \mathrm{L} ; \square, 2 \times 10^{-6} \mathrm{~mol} / \mathrm{L} ; \triangle, 4 \times 10^{-6}$ $\mathrm{mol} / \mathrm{L} ; \nabla, 6 \times 10^{-6} \mathrm{~mol} / \mathrm{L}$. The inset displays the effect of the glutathione concentration on the $a^{*}$ values at 15 min. Reproduced with permission from Ref. 51 ; (c) American Chemical Society.

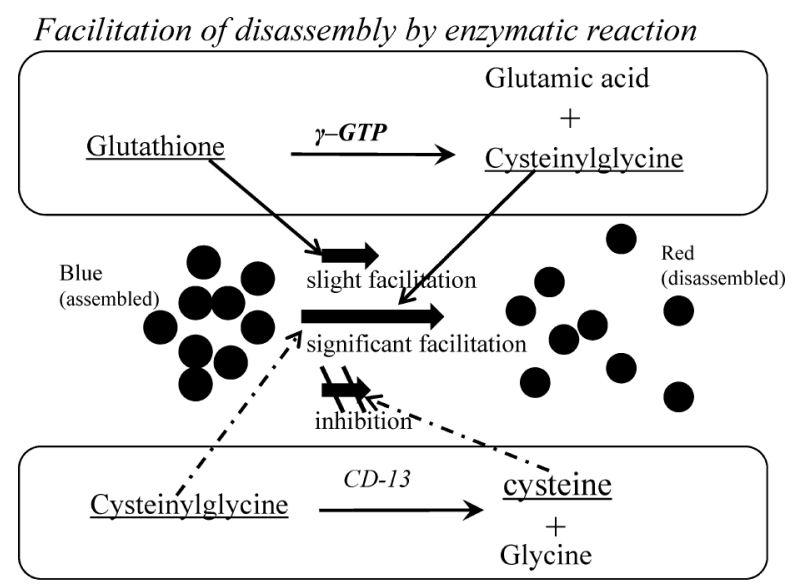

Inhibition of disassembly by enzymatic reaction

Fig. 10 Schematic of assay systems of enzymes based on the inhibition or facilitation of the disassembly of assembled gold nanoparticles in thermoresponsive gold nanocomposites

酵素活性が高い程，溶液の青味が残るようになる．溶液の 色彩を $a^{*}$ 值で数值化することにより 20 〜 $50 \mathrm{U} / \mathrm{L}$ の範囲 における酵素活性を見積もることができる，一方， $\gamma$-GTP 活性を測定する場合には, グルタチオンに比べシステイニ ルグリシンの方が再分散の促進効果が大きいので, 酵素活 性が高い程あるいは酵素と基質との反応時間が長い程, 結 果として再分散が促進されることになる. すなわち, 酵素 活性が高い程, 溶液の赤みが増すことになる．溶液の色彩 


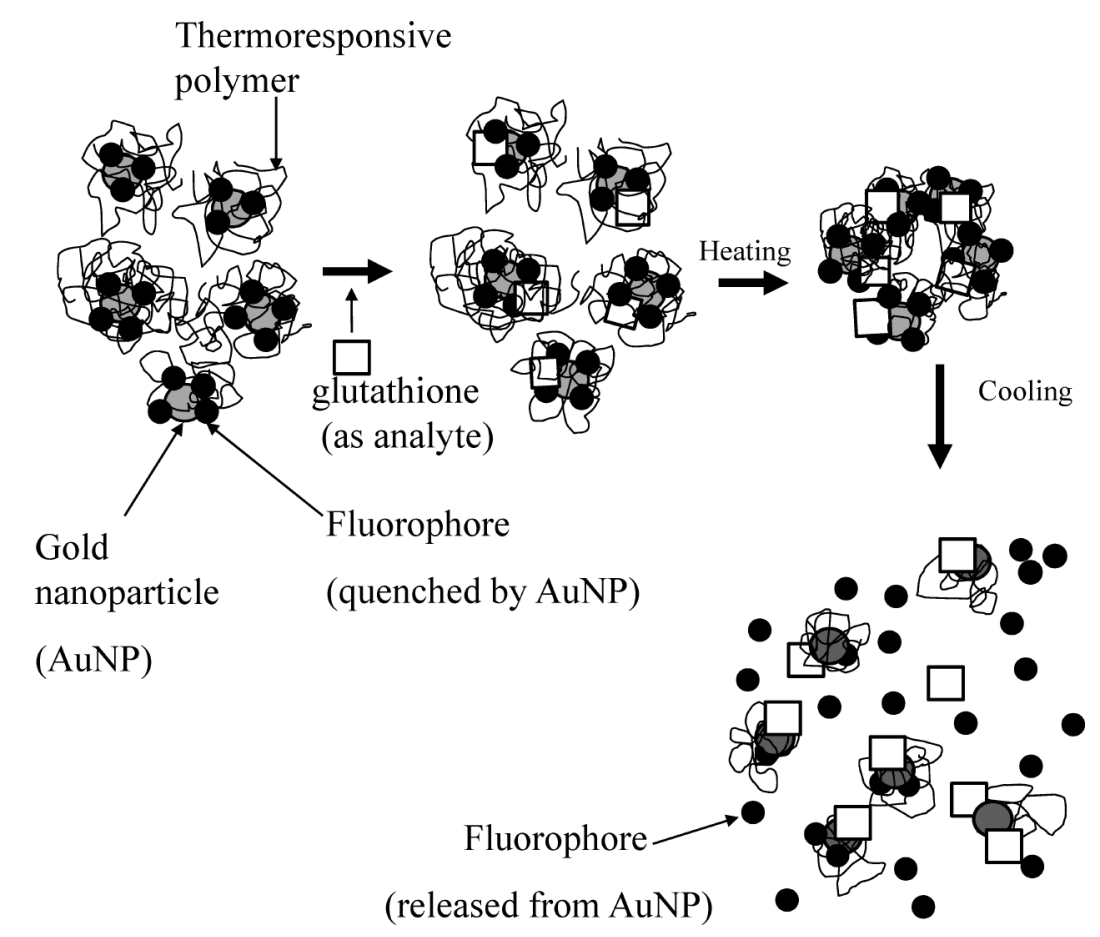

Fig. 11 Schematic of liberation of the fluorophore from gold nanocomposites stimulated by heating and added glutathione

を $a^{*}$ 值で数值化することにより, $8 \mathrm{U} / \mathrm{L}$ までの $\gamma$-GTP 活 性を見積もることができる.

\section{4 熱応答性金ナノ粒子からの蛍光色素の放出 ${ }^{68)}$}

熱応答性金ナノ粒子に蛍光色素を保持させておき, チ オール化合物を共存させた状態で熱刺激をトリガーとして 金ナノ粒子から蛍光色素を放出させることができる.

(Fig. 11) 放出される蛍光色素の量は, 共存させるチオール 化合物の濃度に応じて大きくなる. 金ナノ粒子は蛍光共鳴 エネルギー移動により蛍光色素からの蛍光を消光する. 金 ナノ粒子から放散されると蛍光色素は本来の蛍光を回復す るようになる．この蛍光を測定することで，チオール化合 物の濃度を知ることができる. 既に, 金ナノ粒子に蛍光色 素を吸着させておき, チオール化合物により置換反応の結 果遊離する蛍光色素からの発する蛍光を測定することで, チオール化合物を分析する方法が報告されている ${ }^{63)}$. しか しながら，色素を吸着した金ナノ粒子では分散安定性が低 下してしまうため, 時間とともに凝集し沈降するようにな る.このことが定量性の低下を引き起こす.

これに対して, 熱応答性金ナノ複合体の場合には, 熱応 答性高分子による分散安定性を保っており, 蛍光分子が封 入されていても沈降することはない. 著者らは蛍光分子を 熱応答性金ナノ粒子に封入するために, 最初に蛍光分子を 金ナノ粒子に吸着させ, 次いで熱応答性高分子, $p$ (NIPTETA) を用いて金ナノ複合体を調製した.このときトリエ チレンテトラミン基により金ナノ粒子が凝集し, 凝集体内
部に効果的に蛍光分子が封入される. グルタチオンはチ オール基を介して吸着する際に，蛍光分子を金ナノ粒子表 面から遊離させるだけでなく，同時に金ナノ粒子の再分散 も促進するので, 共存させるチオール化合物として最も適 していた. 放散される蛍光物質の量は, 加熱温度の上昇, グルタチオン濃度の増加とともに増える。 このシステムで は加熱, 冷却後の熱応答性金ナノ粒子溶液の蛍光強度を測 定することで, $10^{-6} \mathrm{~mol} \mathrm{dm}{ }^{-3}$ レベルのグルタチオンを計 測することができる。

5 熱刺激による金ナノ粒子の融合（ナノプロセッ シング $)^{69)}$

これまで粒径が $13 \mathrm{~nm}$ 程度の金ナノ粒子を用いて熱応 答性高分子との複合体に関し，その計測機能の開発につい て概説してきた. $13 \mathrm{~nm}$ 程度の金ナノ粒子はバルクの金と ほほ同様な化学的安定を持つ.しかしながら，金ナノ粒子 は粒径が小さくなると表面エネルギーが大きくなるため, その表面は触媒活性といった反応性を持つょうにな $ろ^{70) 71)}$. これにより, 粒径の小さな金ナノ粒子を用いて調 製した金ナノ複合体にはこれまで検討してきた熱応答性金 ナノ複合体とは異なる機能の発現が期待される.ここでは 金ナノクラスターと呼ばれる粒径が $2 \sim 3 \mathrm{~nm}$ 程度の金ナ ノ粒子に熱応答性高分子を被覆した熱応答性金ナノ複合体 に，加熱冷却といった熱刺激を与えた結果について紹介す る.

Fig. 12 に示す TEM 像に見られるように, 金ナノクラス 
ターに熱応答性高分子を被覆した熱応答性金ナノ複合体に 熱刺激を与えると, 金ナノクラスターが融合し粒径が $80 \mathrm{~nm}$ 程度の金ナノ粒子が生成する，融合により生成した 金ナノ粒子には結晶粒界は観察されない. Fig. 13 には, 熱 応答性高分子と金ナノクラスターを含む溶液の加熱・冷却 前後における消光スペクトル及び極大消光波長における消 光の程度 (吸光度で表している) と平均粒径を加熱温度の 関数として示す. 再分散と同様に, 金ナノ粒子の融合は熱 応答性高分子の相転移温度以上の温度領域において進行す る.このため加熱温度の上昇により, 平均粒径が大きくな る.これに対して, 極大消光波長は加熱温度にはあまり影 響を受けていないことが Fig. 13a）の吸収スペクトルから 分かる. 極大消光波長は平均粒径と関係づけられることか

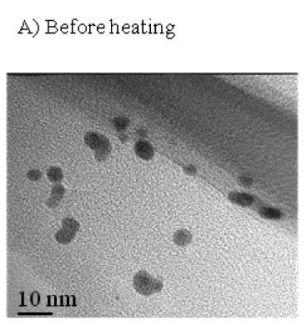

C) Heating at $70^{\circ} \mathrm{C}$
B) Heating at $50^{\circ} \mathrm{C}$

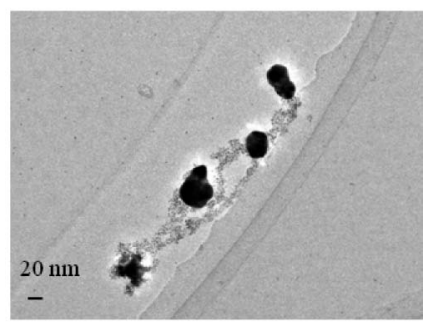

D) Heating $90^{\circ} \mathrm{C}$

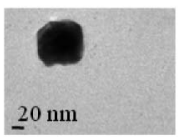

Fig. 12 TEM images of gold nanoparticles generated from gold nanoclusters by thermal stimuli

Reproduced with permission from Ref. 69 ; (c) Elsevier.
$ら^{72)}$ 73)，加熱温度の上昇による平均粒径の増加は個々の粒 子が成長することによるものではなく，粒径の大きな粒子 の数が増えることによるものと考えられる.ここでは, 熱 刺激による金ナノ粒子の融合現象をナノプロセッシングと 呼ぶことにする.

高分子鎖の脱水和に伴う熱応答性高分子の収縮が融合の 駆動力となることから，高分子鎖の収縮がより進む高温に おいて粒子の融合が進むものと考えられる．これまで，粒 子径が $50 \mathrm{~nm}$ を越える金ナノ粒子は, 主に種粒子に金を還 元堆積させることで調製されてきた ${ }^{73)}$ 74). これに対してこ の方法は，還元反応を用いずに金ナノ粒子を成長させるこ とができるので, ナノプロセッシングは粒径の大きな金ナ ノ粒子の新しい調製方法として利用できる.

金ナノクラスター溶液にチオール化合物を加えると, チ オール化合物が金ナノクラスター表面に吸着し, 金ナノ粒 子同士の接触を妨げる. このため, ナノプロセッシングが 抑制される．検討したどのチオール化合物でも，その添加 量の増加とともにナノプロセッシングが強く抑制された. これにより, 加熱冷却後における金ナノクラスター溶液の $520 \mathrm{~nm}$ における消光の増加は抑制される.この応答はチ オール化合物のセンシングの可能性を示唆しているもの の, 現段階ではまだ化合物選択性に課題が残されている. しかしながら, ナノプロセッシングは新しい金ナノ粒子の 成長法としても魅力的であり，様々な可能性について現在 詳細な検討を行っている.

$$
6 \text { 結 言 }
$$

熱応答性高分子と金ナノ粒子を複合化して調製される熱 応答性金ナノ複合体に内在する機能の開発について, 計測 化学的な観点からの検討について紹介した．特にチオール 基を有するぺプチドは生体内において重要な役割を果たし
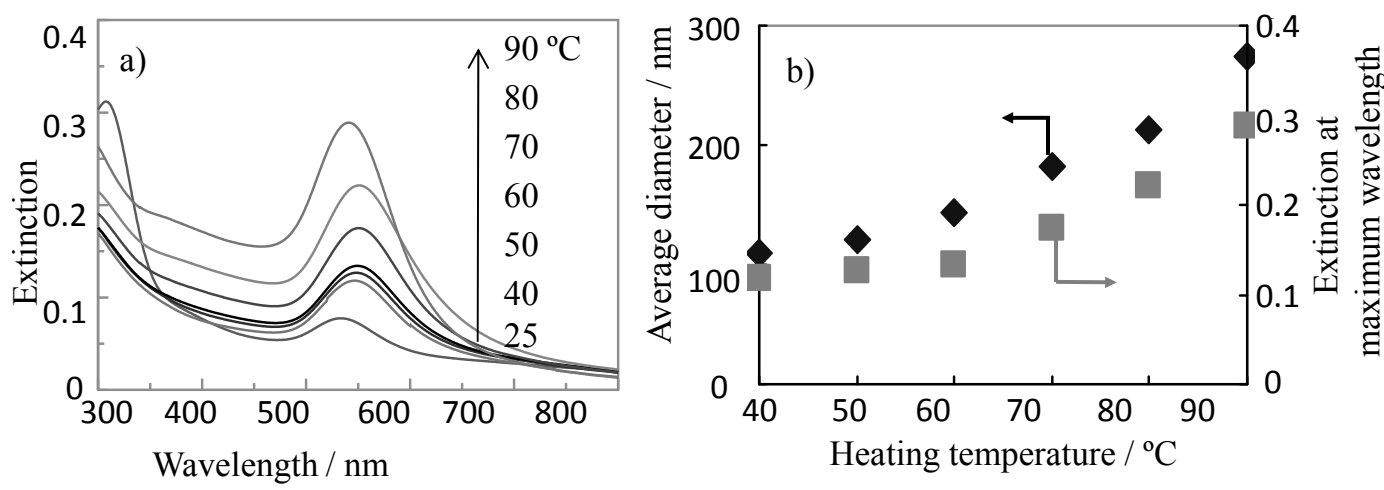

Fig. 13 Extinction spectra of gold nanoparticles generated after heating a solution a), and average diameter and their extinction at maximum wavelength of resulting gold nanoparticles b)

Gold nanoparticle solutions containing $0.014 \mathrm{~g}$ of $\mathrm{Au} / \mathrm{L}$ and $1.0 \mathrm{wt} \%$ of P-NIP are heated for $30 \mathrm{~min}$ followed by cooled at $4{ }^{\circ} \mathrm{C} 1 \mathrm{~h}$. Reproduced with permission from Ref. 69 ; () Elsevier. 
ていることから，簡便な計測については強いニーズがあ る. 熱応答性金ナノ複合体には高分子の持つ分子ふるい機 能や金ナノ粒子の触媒活性や吸着機能など，まだまだ未開 発の機能が内在している. これらを協働的に動作させるこ とで，予測しえなかった機能を引き出すことができるもの と期待される.

\section{文献}

1）金澤将史，南部杏子，鈴木祐輔，西川真由美，金澤 秀子：分析化学 (Bunseki Kagaku), 56, 397 (2007).

2) R. Liu, M. Fraylich, B. R. Saunders : Colloid. Polym. Sci., 287, 627 (2009).

3) 齋藤 徹, 松原チヨ, 平出正孝: 分析化学 (Bunseki Kagaku), 52, 221 (2003).

4) W. Xiaohui, Q. Xingping, W. Chi : Macromolecules, 31, 2972 (1998).

5) J. Chen, X. Gong, H. Yang, Y. Yao, M. Xu, Q. Chen, R. Cheng: Macromolecules, 44, 6227 (2011).

6) T. Saitoh, T. Ohyama, T. Sakurai, T. Kaise, K. Takamura, Y. Suzuki, C. Matsubara : Talanta, 46, 541 (1998).

7) T. Tanaka, Y. Ando, T. Saitoh, M. Hiraide : J. Anal. At. Spectrom., 17, 1556 (2002).

8) T. Saitoh, S. Ohkubo, C. Matsubara : Chem. Lett., 1999, 151.

9) T. Saitoh, M. Haga, T. Sakurai, T. Kaise, C. Matsubara: Anal. Sci., 14, 929 (1998).

10) T. Saitoh, F. Satoh, M. Hiraide : Talanta, 61, 811 (2003).

11) 田鎖和代, 上原伸夫, 清水得夫 : 分析化学 (Bunseki Kagaku), 50, 257 (2001).

12) T. Saitoh, Y. Suzuki, M. Hiraide : Anal. Sci., 18, 203 (2002).

13) J. J. N. Matthias, B. Ruediger, J. Ulrich : Langmuir, 26, 7262 (2010).

14) H. E. Marianne, T. Mary, F. W. Curtis : Polymer, 44, 4547 (2003)

15) 中山正道 : Drug delivery system, 23, 627 (2008).

16) S. Dirk: Adv. Drug Delivery Rev., 58, 1655 (2006).

17) M. Nakayama, T. Okano: J. Drug Delivery Sci. Technol., 16, 35 (2006).

18) R. Yoshida, K. Sakai, T. Okano, Y. Sakurai : Adv. Drug Delivery Rev., 11, 85 (1993).

19) G. Schmid: "Clusters and Colloids : From Theory to Applications", (1994), (VCH, New York).

20) A. Henglein : J. Phys. Chem., 97, 5457 (1993).

21) M. L. Sandrock, C. A. Foss, Jr. : J. Phys. Chem. B, 103, 11398 (1999).

22) Y. Takeuchi, T. Ida, K. Kimura : Surf. Rev. Lett., 3, 1205 (1996).

23) Z. Zhong, S. Patskovskyy, P. Bouvrette, J. H. T. Luong, A. Gedanken : J. Phys. Chem. B, 108, 4046 (2004).

24) S. Link, M. A. El-Sayed : J. Phys. Chem. B, 103, 8410 (1999).

25) C. S. Thaxton, D. G. Georganopoulou, C. A. Mirkin : Clin. Chim. Acta, 363, 120 (2006).

26) 上原伸夫：ぶんせき (Bunseki), 2010, 641.

27) 長岡 勉：ぶんせき (Bunseki), 2008, 476.

28) 長岡 勉, 椎木 弘, 床波志保: 分析化学 (Bunseki Kagaku), 56, 201 (2007).
29) C. A. Mirkin, R. L. Letsinger, R. C. Mucic, J. J. Storhoff : Nature, 382, 607 (1996).

30) K. Sato, K. Hosokawa, M. Maeda : J. Am. Chem. Soc., 125, 8012 (2003).

31) Y. Kim, R. C. Johnson, J. T. Hupp : Nano Lett., 1, 165 (2001).

32) T. B. Norsten, B. L. Frankamp, V. M. Rotello : Nano Lett., 2, 1345 (2002).

33) S. O. Obare, R. E. Hollowell, C. J. Murphy : Langmuir, 18, 10407 (2002).

34) J.-M. Nam, S.-J. Park, C. A. Mirkin : J. Am. Chem. Soc., 124, 3820 (2002).

35) P. J. Costanzo, T. E. Patten, T. A. P. Seery : Chem. Mater., 16, 1775 (2004).

36) H. Otsuka, Y. Akiyama, Y. Nagasaki, K. Kataoka : J. Am. Chem. Soc., 123, 8226 (2001).

37) C-C. Huang, Y-F. Huang, Z. Cao, W. Tan, H-T. Chang: Anal. Chem., 77, 5735 (2005).

38) S.-Y. Lin, S.-W. Liu, C.-M. Lin, C. Chen : Anal. Chem., 74, 330 (2002).

39) 上原伸夫：ぶんせき (Bunseki), 2009, 379.

40) N. Uehara, T. Nagaoka: "Nanomaterials for the Life Sciences Vol. 8 Nanocomposites, Chapter 6 Gold-polymer Nanocomposite”, Edited by C. Kumar, p. 199 (2010), (Wiley-Vch, Weinheim).

41) U. Nobuo : Anal. Sci., 26, 1219 (2010).

42) M.-Q. Zhu, L.-Q. Wang, G. J. Exarhos, A. D. Q. Li : J. Am. Chem. Soc., 126, 2656 (2004).

43) D. J. Kim, S. M. Kang, B. Kong, W.-J. Kim, H. Paik, H. Choi, I. S. Choi : Macromol. Chem. Phys., 206, 1941 (2005).

44) R. R. Bhattacharjee, M. T. K. Chakraborty, T. K. Mandal : J. Phys Chem., B, 110, 6768 (2006).

45) J. Raula, J. Shan, M. Nuopponen, A. Niskanen, H. Jiang, E. I. Kauppinen, H. Tenhu : Langmuir, 19, 3499 (2003).

46) Y. Wang, G. Wei, F. Wen, X. Zhang, W. Zhang, L. Shi : J. Mol. Catal. A, 280, 1 (2008).

47) S. J. Hurst, M. S. Han, A. K. R. Lytton-Jean, C. A. Mirkin : Anal. Chem., 79, 7201 (2007).

48) K. Okubo, T. Shimada, T. Shimizu, N. Uehara : Anal. Sci., 23, 85 (2007).

49) T. Shimada, K. Ookubo, N. Komuro, T. Shimizu, N. Uehara : Langmuir, 23, 11225 (2007).

50 ) 矢野雄志, 上原伸夫, 清水得夫 : 日本分析化学会 第 68 討論会講演要旨集, p. 171 (2007).

51) N. Uehara, K. Ookubo, T. Shimizu : Langmuir, 26, 6818 (2010).

52) N. Uehara, M. Fujita, T. Shimizu : Anal. Sci., 25, 267 (2009).

53）上原伸夫，大久保幸輝，野呂純二，清水得夫：日 本分析化学会第 69 討論会講演要旨集, p. 107 (2008).

54) S. O. Slusser, L. W. Grotyohann, L. F. Martin, R. C., Jr. Scaduto : Am. J. Phys., 258, F1547 (1990).

55) D. W. Jacobsen : Clin. Chem., 44, 1833 (1998).

56) K. Rasmussen, J. Moller: Ann. Clin. Biochem., 37, 627 (2000).

57) I. Graham : Ann. Intern. Med., 131, 387 (1999).

58) P. Quadri, C. Fragiacomo, R. Pezzati, E. Zanda, G. Forloni, M. Tettamanti, U. Lucca: Am. J. Clin. Nutr., 80, 114 (2004).

59) I-I. S. Lim, W. Ip, E. Crew, P. N. Njoki, D. Mott, C.-J. Zhong, Y. Pan, S. Zhou : Langmuir, 23, 826 (2007). 
60) A. T. Gates, S. O. Fakayode, M. Lowry, G. M. Ganea, A. Murugeshu, J. W. Robinson, R. M. Strongin, I. M. Warner: Langmuir, 24, 4107 (2008).

61) F. X. Zhang, L. Han, L. B. Israel, J. G. Daras, M. M. Maye, N. K. Ly, C.-J. Zhong: Analyst, 127, 462 (2002).

62) C.-C. Huang, W.-L. Tseng : Anal. Chem., 80, 6345 (2008).

63) S.-J. Chen, H.-T. Chang: Anal. Chem., 76, 3727 (2004).

64) I-I. S. Lim, D. Mott, W. Ip, P. N. Njoki, Y. Pan, S. Zhou, C.-J. Zhong : Langmuir, 24, 8857 (2008).

65) R. Kunii, E. Nemoto, S. Kanaya, T. Tsubahara, H. Shimauchi : J. Period. Res., 40, 138 (2005).

66) J. Kawamura, Y. Shimada, H. Kitaichi, I. Komoto, Y. Hashimoto, J. Kaganoi, M. Miyake, S. Yamasaki, K. Kondo, M. Imamura : Hepato-Gastroenterology, 54, 36 (2007).
67) M. Yamashita, H. Kajiyama, M. Terauchi, K. Shibata, K. Ino, A. Nawa, S. Mizutani, F. Kikkawa : Int. J. Cancer, 120, 2243 (2007).

68) 吉田 蔵, 上原伸夫, 清水得夫：日本分析化学会 第 59 年会講演要旨集, p. 369 (2011).

69) N. Uehara, M. Fujita, T. Shimizu : J. Coll. Int. Sci., 359, 142 (2011).

70) S. Wunder, Y. Lu, M. Albrecht, M. Ballauff : ACS Catalysis, 1, 908 (2011).

71) W. Lv, Y. Wang, W. Feng, J. Qi, G. Zhang, F. Zhang, X. Fan : J. Mater. Chem., 21, 6173 (2011).

72) W. Haiss, N. T. K. Thanh, J. Aveyard, D. G. Fernig : Anal. Chem., 79, 4215 (2007).

73) P. N. Njoki, I-I. S. Lim, D. Mott, H.-Y. Park, B. Khan, S. Mishra, R. Sujakumar, J. Luo, C.-J. Zhong: J. Phys. Chem. C, 111, 14664 (2007).

74) W. Haiss, N. T. K. Thanh, J. Aveyard, D. G. Fernig : Anal. Chem., 79, 4215 (2007).

\title{
Sensing of Sulfhydryl Compounds with Thermoresponsive Gold Nanocomposites
}

\author{
Nobuo UEHARA $^{1}$ \\ ${ }^{\circledR}$ E-mail : ueharan@cc.utsunomiya-u.ac.jp \\ ${ }^{1}$ Graduate School of Engineering, Utsunomiya University, 7-1-2, Yoto, Utsunomiya-shi, Tochigi 321-8585
}

(Received January 17, 2012 ; Accepted April 10, 2012)

Sensing of sulfhydryl compounds with thermoresponsive gold nanocomposites was reviewed based on research conducted by the present author. The combination of thermoresponsive polymers and gold nanoparticles enabled us to develop not only their inherent functions, but also new functions that would produce novel analytical systems. Aggregated gold nanoparticles in thermoresponsive gold nanocomposites became disassembled by thermal stimuli ; heating followed by cooling, resulting in a change in the solution color from bluepurple to red. Several colorimetric assay systems were fabricated by using gold nanocomposites based on the facts that cysteine prohibited disassembly of the gold nanocomposites while glutathione facilitated the disassembly. The replacement of the other thermoresponsive polymer conjugated with gold nanoparticles allowed us to develop another colorimetric system of the sulfhydryl amino acid, such as homocysteine, with high selectivity. In addition to the sensing systems, spontaneous growth of small gold nanoparticles $(c a .2 \mathrm{~nm})$ conjugated with thermoresponsive polymer was also discussed from the viewpoint of a phase transition induced by heating a solution. Sulfhydryl compounds inhibited growth of the gold nanocomposites, resulting in a suppression of the development of reddish color.

Keywords : sensing ; sulfhydryl compounds ; gold nanoparticles ; thermoresponsive polymers. 